\title{
Gender Gap in the Authorship of Gynecology and Obstetrics Literature in Turkey: An Evaluation From 1995 to 2020
}

\author{
Türkiye Kadın Hastalıları ve Doğum Alanyazın Makale Yazarlı̆̆ı Cinsiyet Trendleri: 1995-2020 Yilları Arası Bir
}

Değerlendirme

\section{${ }^{1}$ Imran Gokcen Yilmaz Karaman, ${ }^{2}$ Gülhan Sagiroglu Muslu, ${ }^{3}$ Ayșe Betul Albayrak Denizli,}

${ }^{1}$ Eskisehir Osmangazi University, Faculty of Medicine, Department of Psychiatry, Eskişehir, Turkey

${ }^{2}$ Diako Flensburg Hospital, Gynecology and Obstetrics Clinic Flensburg, Germany

${ }^{3}$ S.B.Ü Zeynep Kamil Gynecology and Pediatrics Training and Research Hospital, Istanbul, Turkey
Correspondence:

İmran Gökçen YILMAZ KARAMAN Eskisehir Osmangazi University, Faculty of Medicine, Department of Psychiatry, Eskișehir, Turkey,

e-mail: gokcenylmz@yahoo.com

\section{Abstract}

Although it is not the only output of academic productivity and representation, authorship can be considered as an important outcome. The present study aims to explore obstetrics and gynecology literature in Turkey, to assess the representation of women in academic journals as the author, of the male gender, and the inter-annual variation of article types. The journals which were indexed in the Scientific and Technological Research Council of Turkey, National Academic Network and Information Center's Turkish journal index in 2020, were included in the study. The volumes of the journals in 1995, 2000, 2005, 2010, 2015, and 2020, investigated online. Year of the articles, gender of the first author, gender of the last author, gender of corresponder author, number of female authors, number of male authors were coded.The variables of year, first author gender, last author gender, correspondent author gender, number of female authors, number of male authors were coded. A total of 1312 articles from 7 journals were analyzed. The gender inequality in the position of the first writer has been closed by years, and the gender inequality in the position of the writer responsible for correspondence has disappeared; however, there was no statistically significant change in the position of the last author from 1995 to 2020. In order to eliminate the current inequality in leadership positions, the clinical and educational work should be shared among the academicians in a balanced way, work environments where work life balance can be achieved should be created, sexual harassment and gender-based discrimination should not be tolerated.

Keywords: ITP, fragility, treatment outcomes, older adults

\section{Özet}

Makale yazarlığı akademik üretkenliğin ve temsiliyetin tek çıktısı olmamakla birlikte, önemli bir çıktısı olarak değerlendirilebilir. Çalışmamız Türkiye’de kadın hastalıkları ve doğum akademik dergilerinde kadın ve erkek cinsiyetlerinin yazar olarak temsiliyetini ve makale türünün yıllar arası değişimini araștırmayı amaçlamaktadır. 2020 yılında Türkiye Bilimsel ve Teknolojik Araştırma Kurumu Ulusal Akademik Ağ ve Bilgi Merkezi tarafından oluşturulan Türkçe dergi dizininde yer almış dergilerin 1995, 2000, 2005, 2010, 2015 ve 2020 yıllarında yayınlanmış sayılarından çevrimiçi ulaşılabilenler çalışmamıza dâhil edilmiştir. Makalelerin yıl, ilk yazar cinsiyeti, son yazar cinsiyeti, yazışmadan sorumlu yazar cinsiyeti, kadın yazar sayısı, erkek yazar sayısı değişkenleri kodlanmıştır Toplam 7 dergiden 1312 makale incelenmiştir. İlk yazar konumundaki cinsiyet eşitsizliğinin yıllara göre kapandığı, yazışmadan sorumlu yazar konumundaki cinsiyet eşitsizliğinin kaybolduğu; ancak son yazar konumunda 1995 yılından 2020 yılına dek istatistiksel olarak anlamlı bir değişme olmadığı görülmüştür. Liderlik konumlarındaki mevcut eşitsizliğin giderilebilmesi için akademisyenler arasında klinisyenlik ve eğitim görevlerinin dengeli bir biçimde paylaştırılması, iş ve özel hayat dengesinin sağlanabileceği çalıșma ortamlarının yaratılması, cinsel tacize ve cinsiyete dayalı ayrımcılığa tolerans gösterilmemesi önerilmektedir.

Anahtar Kelimeler: cinsiyet eşitliği, toplumsal cinsiyet, yazarlık, kadın hastalıkları, doğum 


\section{Introduction}

Social expectations based on biological sex are defined as gender. Physicians, as individuals, cannot be free from the social structures they live in, and they may have a gender-biased perspective both towards their colleagues and patients in their work environment and their private lives. This situation causes an asymmetry between women and men in terms of clinical and academic career opportunities (1).

Gender inequality has been continuing to negatively affect women's science careers for centuries. While achieving the right to education was a priority problem in the past, today there is an imbalance between women and men against women in terms of holding leadership positions. In America, a similar number of women and men earn doctoral degrees, while the majority of the faculty members are men. It is also known that female academicians who are in the same position as men and doing the job receive lower wages (2).

The representation of women on an equal basis with men in medical academic publications and medical research is important for patients, science, and general public health (3). The way to eliminate inequality in these areas is to be aware of the inequality. Gender distributions in important areas such as awards and appointments in institutions should be published consistently and transparently (4). Thus, it can contribute to the creation of a positive corporate culture in the context of gender equality.

Although it is not the only outcome of academic productivity and representation, academic publishing can be considered an important outcome. As a matter of fact, it is stipulated by universities for first appointments and reappointments (5).

Having a female patient, as a rule, obstetrics and gynecology practices are especially important for women's health and structural health equity. Regarding gender inequality and racism have similar social dynamics, research shows patients from ethnic minorities may get better treatment outcomes with the doctors from ethnic minorities (6). Women can be considered as the biggest minority of the world: not because of their number, but because they do not have equal power, rights, and opportunities with men (7). We think it is important to assess women's contribution to academic publishing in the area which focuses on women.

In this context, our study aims to investigate the trends in the representation of female and male genders as authors and the article type in academic journals of obstetrics and gynecology in Turkey.

\section{Materials and Method}

In 2020, the journals included in the Turkish journal index created by the Scientific and Technological Research Council of Turkey (TÜBİTAK) National Academic Network and Information Center (ULAKBİM) were included in our study. In the search engine of the directory at https://app.trdizin.gov.tr/statistics/listAccepte dJournals.xhtml, by selecting "subject area" and "journal name", a total of 6 calls were made. General medical journals and journals that were not published in 2020 were eliminated from the results, and a total of 7 journals were reached (See Table 1). The online issues of the journals published in 1995, 2000, 2005, 2010, 2015, and 2020 were included in our study. Congress special supplements and correction notes (erratum) of journals were excluded from the study. Published CVs were excluded from the study. The variables of year, first author gender, last author gender, responsible author gender, number of female authors, number of male authors were coded by two gynecologists and obstetricians. Articles other than obstetrics and gynecology were excluded from the study (for example, articles focusing on the field of pediatrics). 
Table 1. Journals included in the study, the number of articles that can be accessed online

\begin{tabular}{|c|c|c|c|c|c|c|c|c|c|}
\hline \multirow{3}{*}{$\begin{array}{l}\text { Journal } \\
\text { Order } \\
\text { Number } \\
1\end{array}$} & \multirow[t]{2}{*}{ Journal Name } & \multirow{2}{*}{$\begin{array}{l}\text { Year of } \\
\text { publication }\end{array}$} & \multirow{2}{*}{$\begin{array}{ll}\text { Number } & \text { of } \\
\text { publications/ } & \\
\text { year } & \end{array}$} & \multicolumn{6}{|c|}{ Number of articles available online } \\
\hline & & & & 1995 & 2000 & 2005 & 2010 & 2015 & 2020 \\
\hline & $\begin{array}{l}\text { Zeynep Kamil Tip } \\
\text { Bülteni }\end{array}$ & 1969 & 4 & - & - & 21 & 21 & 20 & 25 \\
\hline 2 & $\begin{array}{l}\text { Journal of Clinical } \\
\text { Obstetrics \&ynecology }\end{array}$ & 1991 & 4 & 52 & 58 & 72 & 77 & 56 & 18 \\
\hline 3 & $\begin{array}{l}\text { Perinatoloji } \\
\text { Dergisi }\end{array}$ & 1993 & 3 & 35 & 26 & 41 & 22 & 34 & 24 \\
\hline 4 & $\begin{array}{l}\text { Gynecology } \\
\text { Obstetrics } \quad \& \\
\text { Reproductive } \\
\text { Medicine }\end{array}$ & 1995 & 3 & - & - & 62 & 46 & 44 & 42 \\
\hline 5 & $\begin{array}{l}\text { Journal of the } \\
\text { Turkish-German } \\
\text { Gynecological } \\
\text { Association }\end{array}$ & 2000 & 4 & - & - & 60 & 56 & 39 & 39 \\
\hline 6 & $\begin{array}{lr}\text { Jinekoloji- } & \\
\text { Obstetrik } & v e \\
\text { Neonatoloji } & \text { Tip } \\
\text { Dergisi } & \end{array}$ & 2004 & 4 & - & - & - & - & 45 & 53 \\
\hline 7 & $\begin{array}{l}\text { Turkish Journal of } \\
\text { Obstetrics and } \\
\text { Gynecology }\end{array}$ & 2004 & 4 & - & - & 68 & 60 & 55 & 41 \\
\hline Total nuı & of articles evaluated & y years & & 87 & 84 & 324 & 282 & 293 & 242 \\
\hline
\end{tabular}

In the process of determining the gender of the authors, female names or male names (for example Mary or James, for the English language) were coded directly, for names suitable for both genders (for example Kerry, for the English language), the websites of the authors' institutions and the photographs of the authors on social media accounts such as ResearchGate or LinkedIn were examined. For some authors, when gender information could not be reached with these methods, coding was made by searching for the name on the website https:/genderize.io/ and by looking at which gender the name is most likely.

Since there were no human participants in our study, ethics committee approval was not required considering other bibliometric studies in the literature. Data were collected between January 1, 2021, and January 31, 2021.

\section{Statistical analysis}

IBM SPSS 22.0 version was used for data analysis. One-way analysis of variance (Oneway ANOVA) was used to compare continuous variables by years, and the chi- square test was used for the analysis of categorical variables. When the column proportion is $0-1 \%$, the data is automatically excluded from the analysis by the program used, Bonferroni correction is used for paired comparisons.

\section{Results}

A total of 1312 articles published in 1995, 2000, 2005, 2010, 2015, and 2020 were included in the study (Table 1). The number of female and male authors could not be determined in a 1995 article in which only the surnames of the authors other than the first author were specified. In another article published in 1995, only the surnames of all authors were specified, so the gender of the first author, the last author, and the author responsible for the correspondence, the total number of female authors and the total number of male authors could not be determined. Incomplete data of these two articles were excluded from the analysis.

As stated in Table 2; a trend that resulted in equality in the ratio of the first authorship of the genders and the ratio of correspondence authorship from 1995 to 2020 were 
determined. However, there was no change in the final authorship rates between genders. In terms of article type, it was seen that the rates of research articles were in a downward trend from 1995 to 2010, and then increased to the levels in 1995. Complementary with this trend, the rate of case reports increased from 1995 to 2010, after which it started to decline.

As can be seen in Table 3, the ratio of female authors among the total authors has increased from 1995 to 2020 .

Table 2. Gender ratio of authors by position, article type and article subject in all articles

\begin{tabular}{|c|c|c|c|c|c|c|c|c|c|c|}
\hline & & 1995 & 2000 & 2005 & 2010 & 2015 & 2020 & $\begin{array}{c}\text { Dual } \\
\text { comparison }\end{array}$ & $\begin{array}{l}\text { Chi- } \\
\text { square }\end{array}$ & p \\
\hline 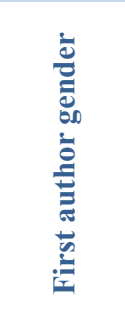 & $\begin{array}{l}\text { Male (\%) } \\
\text { Female }(\%)\end{array}$ & 76.7 & 77.4 & 34.9 & 58.9 & 51.2 & 50.0 & $\begin{array}{l}1995-2010, \\
1995-2015, \\
1995-2020, \\
2000-2010, \\
2000-2015, \\
2000-2020, \\
2005-2015, \\
2005-2020\end{array}$ & $\begin{array}{l}\stackrel{\hat{f}}{\forall} \\
\stackrel{\dot{\vartheta}}{\forall}\end{array}$ & $\begin{array}{l}\bar{\delta} \\
\dot{8} \\
\dot{\rho}\end{array}$ \\
\hline \multirow{2}{*}{ 苞 } & Male $(\%)$ & 69.4 & 72.6 & 71.9 & 73.8 & 68.3 & 64.0 & - & \multirow[b]{2}{*}{ ণ্ণ } & \multirow[b]{2}{*}{ กิ } \\
\hline & Female (\%) & 30.6 & 27.4 & 28.1 & 26.2 & 31.7 & 36.0 & & & \\
\hline 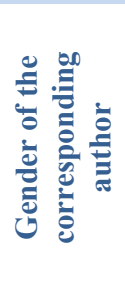 & Male (\%) & 23.3 & 22.6 & 34.9 & 41.1 & 48.8 & 50.0 & $\begin{array}{l}1995-2010, \\
1995-2015, \\
1995-2020, \\
2000-2010, \\
2000-2015, \\
2000-2020, \\
2005-2015, \\
2005-2020\end{array}$ & \multirow[t]{2}{*}{ 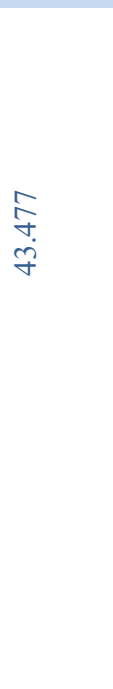 } & $\begin{array}{l}\overrightarrow{8} \\
\dot{0} \\
\dot{v}\end{array}$ \\
\hline \multirow[t]{4}{*}{ 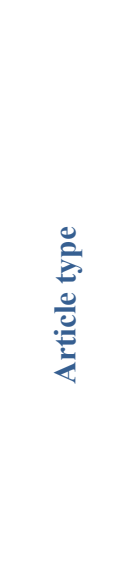 } & $\begin{array}{c}\text { Research } \\
(\%)\end{array}$ & 25.3 & 20.2 & 30.9 & 41.1 & 56.7 & 11.2 & $\begin{array}{l}1995-2005, \\
1995-2010, \\
2005-2020, \\
2010-2020, \\
2015-2020 \\
1995-2020, \\
2000-2010, \\
2005-2020, \\
2010-2015, \\
2010-2020, \\
2015-2020\end{array}$ & & \multirow[b]{4}{*}{$\begin{array}{l}\overline{8} \\
\text { ○. } \\
\dot{v}\end{array}$} \\
\hline & Review (\%) & 2.3 & 8.3 & 12.7 & 7.4 & 10.6 & 11.2 & - & \multirow[b]{3}{*}{$\begin{array}{l}\text { } \\
a \\
\tilde{a}\end{array}$} & \\
\hline & $\begin{array}{l}\text { Letter to } \\
\text { editor }(\%)\end{array}$ & 0 & 0 & 0.6 & 1.8 & 2.0 & 2.5 & - & & \\
\hline & $\begin{array}{l}\text { Editorial } \\
(\%)\end{array}$ & 0 & 4.8 & 3.1 & 0.7 & 2.4 & 0.8 & - & & \\
\hline
\end{tabular}

Table 3. Percentage of female authors in all articles by year

\begin{tabular}{|c|c|c|c|}
\hline Year & Percentage of female authors $(\%)$ & Comparison between groups & $\begin{array}{l}\text { Dual comparison } \\
\text { (year- year: p score) }\end{array}$ \\
\hline \multicolumn{4}{|l|}{1995} \\
\hline & $20.69 \pm 24.34$ & & 1995-2005: 0.005 \\
\hline \multirow[t]{2}{*}{2000} & & & 1995-2010: $<0.001$ \\
\hline & $25.39 \pm 28.54$ & & $1995-2015:<0.001$ \\
\hline \multirow[t]{2}{*}{2005} & & & 1995-2020: $<0.001$ \\
\hline & $33.78 \pm 29.04$ & $\mathrm{~F}=15.010$ & 2000-2010: 0.041 \\
\hline
\end{tabular}




\begin{tabular}{|c|c|c|c|}
\hline 2010 & $36.48 \pm 29.58$ & $\mathrm{p}<0.001$ & $\begin{array}{l}2000-2015:<0.001 \\
2000-2020:<0.001\end{array}$ \\
\hline 2015 & $42.56 \pm 30.56$ & & $\begin{array}{l}2005-2015: 0.004 \\
2005-2020:<0.001\end{array}$ \\
\hline 2020 & $46.02 \pm 31.53$ & & 2010-2020: 0.004 \\
\hline
\end{tabular}

\section{Discussion}

In our study, academic journals on obstetrics and gynecology in Turkey have been examined at 5-year intervals since 1995. In this process, it is stated that the gender inequality in the position of the first author has been closed by years, and the gender inequality in the position of the writer responsible for correspondence disappeared; however, it was observed that there was no statistically significant change in the position of the last author from 1995 to 2020.

In the United States, the rate of women among residents who received training in obstetrics and gynecology increased from $12 \%$ in 1980 to $77 \%$ in $2006(8)$. The reflection of this increase in leadership positions is weak: women constitute $20.4 \%$ of presidents in administrative positions, $36.1 \%$ of vice presidents, and $29.6 \%$ of department heads. It has been reported that gender inequality is observed especially in the field of gynecological oncology (9).

The final author position is an authorship position with senior academics and leaders. The fact that no change has been observed between years in the last authorship can be interpreted as the glass ceiling effect. The term "glass ceiling" defines the inability of women to take leadership positions, even though they have no apparent handicaps. It is thought to have been first brought up by Marilyn Loden. Tesch and Nattinger, on the other hand, as a result of their interviews with doctors of similar seniority, suggested that there were similar invisible obstacles for women to be promoted, and they suggested the term "sticky base" (10). In summary, in the period examined in our study, no rule or law prevents women from receiving medical education and becoming researchers or academics. However, in practice, there is no change in the representation of women in leadership roles.

One of the reasons for this is the asymmetrical distribution of academic time. It has been revealed that women are clinicians and educators rather than research and publication. Some authors have described this situation as "corporate housework" $(10,11)$. Due to the asymmetrical use of time, women lag behind men in productivity measured by publishing. Another reason is that women care more or have to care more about the balance of work and private life due to their social roles. For example, when a woman or a man has a child, their work-life is not equally affected. The work environment and relationships with colleagues can also influence academic leadership positions. It can be predicted that women will stay more frequently and for a longer period in work environments that are free from discrimination, sexual harassment is not experienced, and where women are respected during periods of maternity and breastfeeding (11). In general, it is beneficial to have a balanced workforce of men and women in all branches of medicine (8).

\section{Study Limitations}

Our study was conducted through retrospective records, and the researchers directly coded the commonly used single-sex names. This application method has a certain margin of error. However, since it was not appropriate to state the gender by the author in practice, it was thought that the possible error remained within acceptable limits. Another limitation is that the archive was scanned intermittently, that is, not all publications were examined.

In our study, gender inequality has been taken into consideration. However, the hierarchical patriarchal structure dominates all individuals 
except heterosexual men. Therefore, in an ideal study, homosexual, bisexual, transgender, and non-binary should be stated whether individuals are also properly represented in academic publications. This is not possible with the research method we use.

Regarding the limitations of the present study, it is the first study to examine gender inequality in gynecology and obstetrics academic publications in Turkey.

\section{Conclusion}

Similar to the examples in the world, there is no gender difference in representation

\section{REFERENCES}

1. Risberg G, Johansson EE, Hamberg K. A theoretical model for analysing gender bias in medicine. Int J Equity Health. 2009;8:28.

2. Shen H. Inequality quantified: Mind the gender gap. Nature News. 2013;495:22.

3. Rexrode KM. The gender gap in first authorship of research papers. British Medical Journal Publishing Group; 2016.

4. Boyle PJ, Smith LK, Cooper NJ, Williams KS, O'Connor H. Gender balance: Women are funded more fairly in social science. Nature News. 2015;525:181.

5. Jagsi R, Guancial EA, Worobey CC, Henault LE, Chang Y, Starr R, et al. The "gender gap" in authorship of academic medical literature - a 35year perspective. New England Journal of Medicine. 2006;355:281-7.

6. Anderson SR, Gianola M, Perry JM, Losin EAR. Clinician-Patient Racial/Ethnic Concordance Influences Racial/Ethnic Minority Pain: Evidence from Simulated Clinical Interactions. Pain Medicine. 2020;21:3109-25.

7. Hacker HM. Women as a minority group. Social forces. 1951:60-9.

8. Bibbo C, Bustamante A, Wang L, Friedman Jr F, Chen KT. Toward a better understanding of gender-based performance in the obstetrics and gynecology clerkship: women outscore men on the NBME subject examination at one medical school Academic Medicine. 2015;90:379-83.

9. Hofler L, Hacker MR, Dodge LE, Ricciotti HA. Subspecialty and gender of obstetrics and gynecology faculty in department-based leadership roles. Obstetrics and gynecology. 2015;125:471.

10. Carnes M, Morrissey C, Geller SE. Women's health and women's leadership in academic medicine: hitting the same glass ceiling? Journal of women's health. 2008;17:1453-62. measured by academic publications in Turkey, but women are not sufficiently represented in leadership positions. Having a balanced male and female workforce is important in terms of the quality of the health service provided and the reduction of gender bias in the knowledge constructed.

To eliminate the current inequality in leadership positions, it is recommended that the clinical and educational duties be shared among academics in a balanced manner, that work environments can be created in which work and private life can be balanced, and that sexual harassment and gender-based discrimination are not tolerated.
11. Grinnell $\mathrm{M}$, Higgins $\mathrm{S}$, Yost $\mathrm{K}$, Ochuba O, Lobl $\mathrm{M}$, Grimes $\mathrm{P}$, et al. The proportion of male and female editors in women's health journals: a critical analysis and review of the sex gap. International journal of women's dermatology. 2020;6:7-12. 